\title{
Nutritional inputs into the reproductive neuroendocrine control system - a multidimensional perspective
}

\author{
D Blache', LM Chagas² and GB Martin' \\ 'School of Animal Biology, M085, Faculty of Natural and Agricultural Sciences, The University of \\ Western Australia, 35 Stirling Highway, Crawley, WA 6009, Australia; 'Dexcel, Private Bag 3221 , \\ Hamilton, New Zealand
}

\begin{abstract}
Evolution has shaped regulatory systems to improve the chance of reproductive success in a somewhat unpredictable environment. One of the more powerful regulators of reproductive function in both sexes is metabolic status, defined as the availability of nutrients and energy to the tissues. Here, we briefly review the basics of the relationship between metabolic status and the activity of the system that controls pulsatile $\mathrm{GnRH}$ and $\mathrm{LH}$ secretion. We then reflect on these relationships within the framework of a model that comprises four interdependent 'dimensions': 1) genetic, 2) structural, 3) communicational, and 4) temporal. Using two major examples, the male sheep and the post-partum dairy cow, we illustrate aspects of each dimension that seemed to have evolved to limit the risks associated with 'the decision to reproduce'. The results of recent studies have also led us to include in our model the concepts of 'metabolic memory' and 'nutrient sensing' to help explain some aspects of the temporal dimension. Throughout the review, we propose directions for future research that could shed light on pathways that have evolved to ensure that animals are able to take the least risky 'decision'.
\end{abstract}

\section{Introduction}

In this review, we are looking at how nutrition influences reproduction, an old problem that has been researched for decades and reviewed in detail many times (most recent: Butler 2005; Blache et al. 2006; Robinson et al. 2006). In this instance, we are attempting to analyse the issues from a different perspective - we will consider the multi-dimensional nature of an integrated control system that has developed over an evolutionary timescale to ensure that an animal has the best chance of reproductive success in an unpredictable environment. Of course, for farmed ruminants, the environment is nowadays far more predictable than that with which their ancestors had to cope before domestication. On the other hand, domestication has also led to intense demands, such as selection pressure for increased milk production by modern dairy cows, that greatly increase the energy requirements of the animals - in effect, this is an extreme metabolic stressor that challenges the homeostatic processes developed during evolution. 
Before elaborating the notion of a multi-dimensional control system, we will first define several basic concepts in the bioenergetics of reproduction, metabolic status, and their effects on reproduction. Having set the scene, we will consider each of four 'dimensions' of what we see as a 'decision-making system' that allows ruminants to optimise their reproductive success. First, we will briefly look at the genetic dimension, one that sets the limits of responsiveness to nutritional input to animals. Second, we will consider the structural dimension, a growing list of organs and tissues involved in the linkage between metabolic status and reproduction. The third dimension, the communication network of signalling pathways, will be treated in greater detail. The fourth and final dimension is temporal so concerns the role of time on the metabolism-reproduction relationship - and has led us to incorporate 'metabolic memory' and 'nutrient sensing' into our hypothetical control system (Cahill 1980; Obici \& Rosetti 2003). To illustrate these concepts, we will mainly use two examples, the male sheep that has been acutely placed on a high plane of nutrition, and the high-output dairy cow that is undergoing a dramatic change in energy balance in the early postpartum period. We will conclude by discussing the four-dimensional model as a conceptual framework upon which we can base further study of the interactions between nutrition and reproduction. Most of the processes involved are autonomic by nature but, to aid clarity of expression, we will occasionally risk the use of anthropomorphic language (eg, 'decision to invest').

\section{Basic concepts}

\section{Bioenergetics of reproduction}

Energy costs are attached to all components of the reproductive process, from the expression of specific behaviours, such as sexual or maternal behaviour, to the production of morphological elements, such as gametes, fetuses and milk. In mammals, reproduction is energetically more demanding for females than for males because of the requirements for gestational development and the production of milk. The peaks in energy demand for reproduction also differ in timing between the sexes, with the male investing most energy before fertilization, while females invest most energy following fertilization, often with considerable delay (Horton \& Rowsemitt 1992). For example, in grazing ewes, gestation costs only $3 \%$ of the daily energy expenditure during the first 3 months but this builds rapidly to $20 \%$ during the last 2 months (Fierro \& Bryant 1990). The energy requirement for dairy cows to ovulate a follicle, form a corpus luteum, and maintain early pregnancy is minuscule compared with the requirement for lactation, which requires up to $50 \%$ of the daily energy expenditure (Graham 1964; Fierro \& Bryant 1990). For the human female, it has been suggested that the reproductive axis will not be activated until the energy requirements for pregnancy are already in storage (Frisch 1994) but, in a striking contradiction of this logical concept, dairy cows have been successfully selected genetically for their ability to conceive during lactation when their energy balance is negative.

The critical time point in the reproductive cycle seems to be when the animal makes an 'investment decision', accepts the risks inherent in procreation, and 'switches on' its reproductive system. Considering the energetic requirements, the relationship between the metabolic and the reproductive regulatory systems needs to be highly tuned if the probability of success is to be reasonable. As a natural illustration of this matching of potential future resources to potential future demands, the energy regulatory systems of mammals are more strongly tied to reproductive function in females than in males because of the much higher cost for reproduction paid by females. 
The concept of metabolic status

At any given time, for any given animal, the amount of energy available for reproduction depends on the difference between the amount of energy expended, including the demands for maintenance, and pool of disposable energy (Fig. 1). The pool of disposable energy includes the energy derived from feed intake plus the energy stored in body tissues, especially adipose tissue, liver and muscle. The amount of expended energy varies according to the age and the physiological status of the animal and it comprises the energy spent on functions that are responsible for the maintenance of homeostasis, as well as energy spent on extra physiological needs such as growth and reproduction. Most authors refer to 'energy balance' instead of 'metabolic status'. The terms can be seen as interchangeable but 'metabolic status' includes an integrative dimension that 'energy balance' does not.

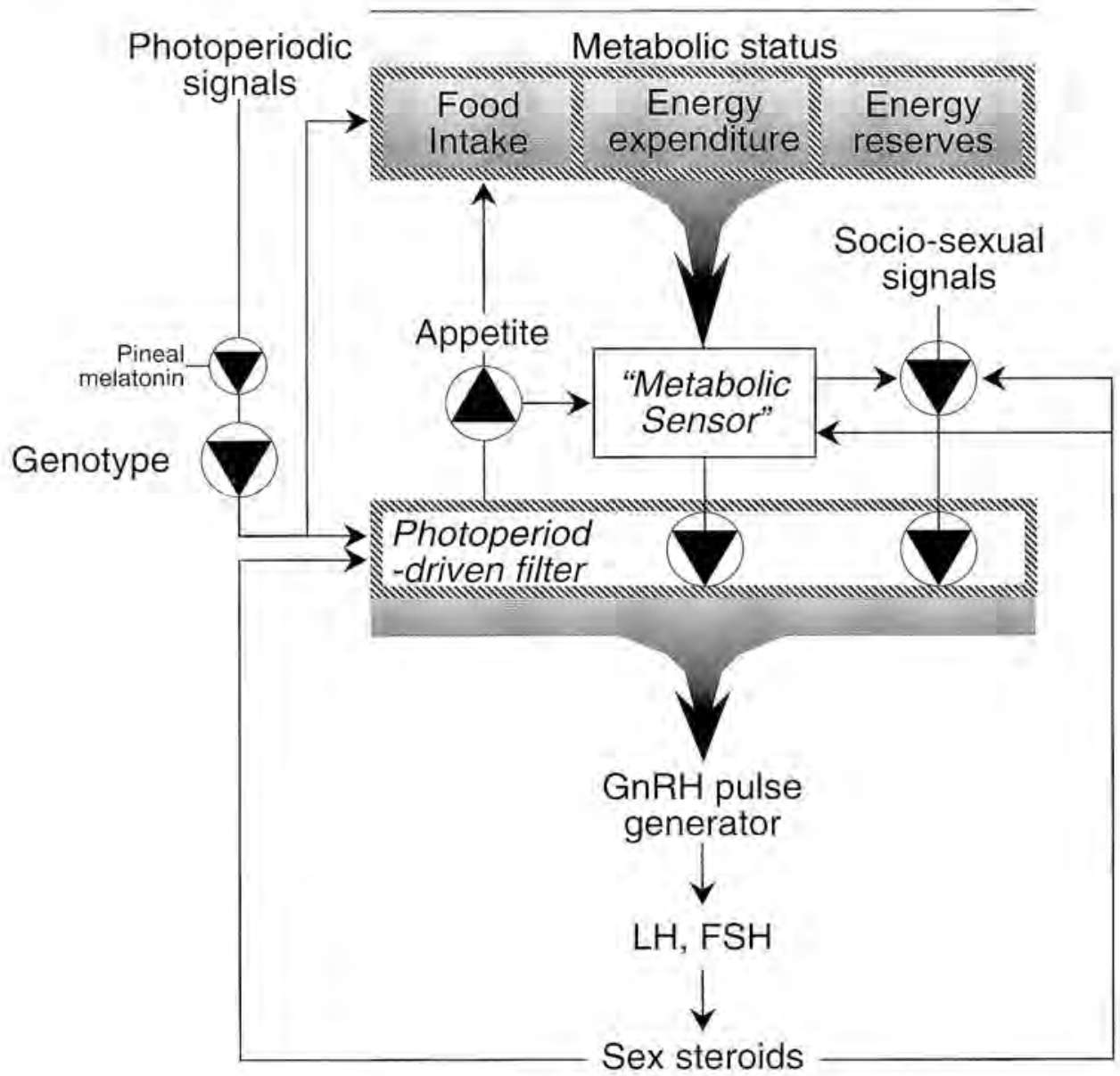

Fig. 1: A schema describing the proposed relationships between photoperiodic, nutritional and social cues and they ways that they interact with genotype and steroid feedback in the control of hypothalamo-pituitary-testicular axis in the male sheep. Nutritional input is via 'metabolic status', a reflection of the difference between energy expenditure and the sum of energy available from food intake and from energy reserves, as measured by a hypothetical 'metabolic sensor'. Redrafted after Blache et al. 2003. 
The neuroendocrine system - the fundamental controller of reproduction

A full reproductive cycle starts with the emergence of sexual activity in future parents and finishes with emergence of sexual activity in the subsequent generation. The various phases of the cycle differ in their duration between the sexes but the secretion of $\mathrm{GnRH}$, and consequently $\mathrm{LH}$ and FSH from the pituitary gland, are central to the process in both (Blache et al. 2002; Blache et al. 2003; 2006). Effectively, the 'decision' of an animal to reproduce or not is implemented by the system, as yet not described, that controls the production of pulses of $\mathrm{GnRH}$ - there is a threshold frequency of pulses above which males will produce sperm and females will ovulate. Thus, during postpartum anoestrous in dairy cattle, pulsatile infusion of $\mathrm{LH}$ decreases the time delay to first ovulation by stimulating follicular growth and steroidogenesis (Hampton et al. 2003). The system that controls GnRH secretion is also the final common pathway via which gonadal activity is usually influenced by external factors (Fig. 1), including socio-sexual cues, photoperiod and energy balance (review: Martin et al, 2004). That said, it is important to note that tissues involved in the process of reproduction, including the pituitary gland, gonads and mammary glands, can also respond independently to metabolic inputs, if not to the extent of switching the reproductive process on or off.

\section{Metabolic status and investment in reproduction}

Because reproduction is very demanding energetically, metabolic status is arguably the most powerful internal regulator of reproductive function and variation in metabolic status can profoundly affect the reproductive cycle at almost any stage. In mature male sheep, an acute increase in the intake of energy and protein induces, first, an increase in the frequency of pulses of GnRH and LH, and then an increase in the tonic secretion of FSH (Martin et al. 1994). An acute reduction of feed intake has the opposite effects (Martin \& Walkden-Brown 1995). Similarly, in the post-partum cow, the activity of the GnRH neurons is highly positively correlated with energy balance, so pulse frequency increases when energy balance shifts from negative to positive values following an increase in intake or a decrease in expenditure (review: Butler 2000; 2005). Dairy cows have been selected heavily for high milk production and show a high level of nutrient utilisation and adipose tissue mobilization during early lactation, so the impact of milk production on reproduction can be reduced by reducing milking frequency. Reducing milking frequency to once daily increases the rate of spontaneous resumption of oestrous cycles in anoestrous cows (Rhodes et al. 1998) independently of any direct effect of diet (Patton et al. 2006), although the role played by $\mathrm{GnRH}$ pulse frequency in determining the length of postpartum anoestrus interval (PPAI) is yet to be proven directly.

\section{A 4-dimensional linkage between nutrition and reproduction}

Naturally, animals have evolved to increase their chances of reproducing and regulatory systems have evolved to fulfil that drive. We will now outline a framework within which we can analyse the processes and relationships involved. Following an analogy with theoretical physics, we will consider the regulatory system as having four dimensions: genetic, structural, communicational and temporal.

\section{1) The genetic dimension}

The effects of metabolic status and dietary manipulation on the reproductive axis differ be- 
tween genotypes in both sheep and cattle. This genetic dimension accounts for variations in the responses to environmental inputs, whether they be natural (eg, photoperiod) or artificial (eg, genetic selection for high milk production). In our review for the previous symposium in this series, we suggested that photoperiod acts as a 'filter' of the effect of nutrition on the reproductive system and that this filtering effect depends on the genotype of the animal (Blache et al. 2003). This is because, in sheep, the effect of nutrition on the reproductive endocrine axis is smaller in breeds that are very responsive to photoperiod than in breeds that are less responsive (Hötzel et al. 2003; Martin et al. 1999; Martin et al. 2002). Similarly, a large body of work in dairy cattle has shown that genotype affects the ability of cows to resume ovulation during the postpartum period. Dairy cows in continuous calving systems that have not ovulated by 44 days postpartum are defined as having a prolonged PPAI (Lamming \& Darwash 1998). It seems that the regulatory systems that control metabolism and energy balance can partition energy in different ways in cows of different merit and, in high merit animals, reproductive function has been de-prioritised in favour of milk production. This was clearly demonstrated in a study done in New Zealand that compared the performance of Friesian cows bred from semen collected in 1970 s and 1990s - over that 20-year period of selection, the postpartum anovulatory interval increased from 7 to 12 days (McNaughton et al. 2003), despite the fact that selection for high milk production was associated with a increase in dry matter intake (Veerkamp et al. 2003). The genetic make-up of an animal, whether naturally or artificially acquired, is thus the first regulatory step in the influence of metabolic status on reproductive function.

\section{2) The structural dimension}

Metabolic status involves inputs from several energy pools that depend on the activity of a variety of organs so it is not surprising that recent decades of research have led to an increasing number and diversity in anatomical sites involved in the relationship between nutrition and reproduction. There has also been a parallel increase our understanding of the precise nature of the role played by each regulatory organ. The brain and the gonads have always been seen as the primary targets for nutritional input into reproductive function but we now accept major roles for the pancreas, liver and adipose tissue (Fig. 2). For adipose tissue, this transformation has been spectacular as it has been elevated from a passive storage site to a vital endocrine organ that produces a number of signals (detailed below). Similarly, the digestive system is also now implicated in the regulatory processes through which nutrition affects reproduction as its endocrine output has been detected and identified. The digestive system also produces very direct metabolic information in the form of energy metabolites (glucose, fatty acids) and amino acids, as detailed in the final section below. In summary, every organ involved in the regulation of the three compartments of metabolic status (intake, reserves, expenditure), is also involved in generating signals that influence reproductive activity (Fig. 2) - some of these have a very specific role (eg, the liver, an organ that processes first most of the circulating nutrients) whereas others have a more general input (eg, the thyroid gland).

\section{3) The communicational dimension}

The successful implementation of a 'decision to invest' in reproduction depends on the systems that regulate the reproductive axis, via changes in GnRH pulse frequency, responding accurately to changes in metabolic status. These regulatory systems can be classified as endocrine. neural and nutrient-based. 


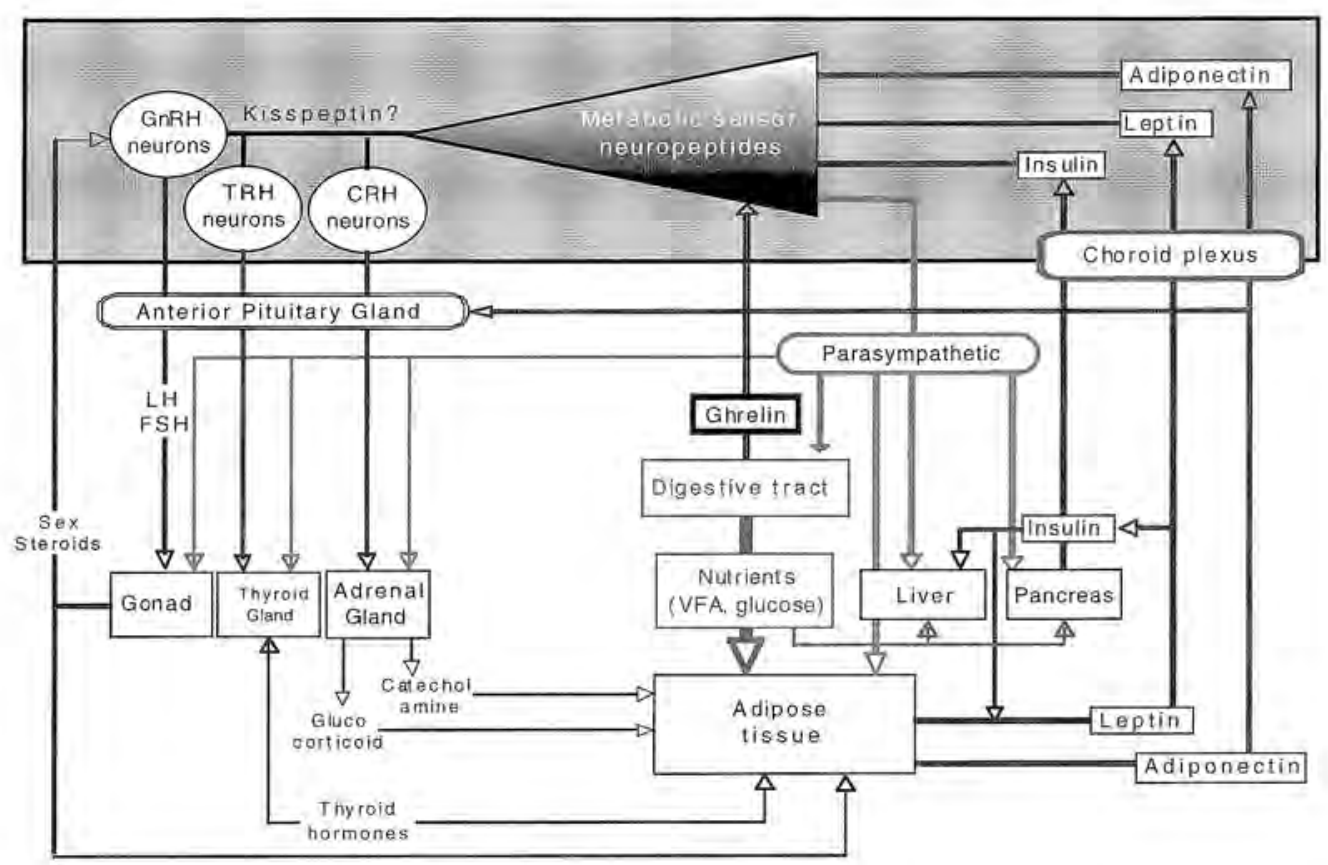

Fig. 2: Schematic summary of the potential relationships among the endocrine and neural inputs into the systems that control the reproductive system and mediate the responses to change in metabolic status. For clarity, we have omitted some hormonal systems $(\mathrm{GH}$, prolactin, oxytocin) that are also involved in the control of the metabolic status but do not appear to exert any direct action on GnRH secretion. Within the brain, the neurochemical nature of the hypothetical 'metabolic sensor' that integrates the endocrine and neural inputs is still not known. Kisspeptin is proposed as a possible final link between the neuropeptide systems that respond to insulin and leptin, and perhaps adiponectin, and the GnRH neurons. It should be noted that the pituitary gland might be involved in the response of the reproductive axis to nutrition because it is responsive to many of the same hormonal signals as the hypothalamus.

\section{Endocrine systems linking metabolic status and GnRH secretion}

\section{Insulin}

Insulin is affected by energy balance and seems to be involved in the control of reproduction in male sheep because: 1) a high plane of nutrition leads to high concentrations of insulin in both plasma and CSF (Miller et al. 1998; Zhang et al. 2004; 2005); 2) with a restricted diet or with diabetes, a low dose of insulin infused into the third ventricle increases $\mathrm{LH}$ pulse frequency to values similar to those seen in well-fed animals (Miller et al. 1995a; Miller et al. 2002; Tanaka et al. 2000); 3) insulin receptors are present in the hypothalamus (Blache et al, 2002); 4) following an acute increase in dietary allowance, the increase in insulin secretion coincides with the increase in LH pulse frequency (Zhang et al. 2004). A central role for insulin in the regulation of $\mathrm{GnRH}$ secretion is also supported by studies with neuron-specific, insulin receptor knockout mice (Bruning et al. 2000). 
In cattle, there are also similar associations: 1) dietary restriction and negative energy balance reduce plasma concentrations of insulin; 2) during post-partum anoestrus, the dominant follicle ovulates in response to restricted suckling only in cattle with high plasma concentrations of insulin (Sinclair et al. 2002); 3) dietary manipulation that increases plasma concentrations of propionate and insulin are also associated with a decrease in PPAI without any changes in either milk production or energy balance (Gong et al. 2002).

Thus, the accumulated evidence strongly suggests a major role for insulin in the $\mathrm{GnRH}$ response to variation in metabolic status, although, in dairy cattle, the evidence for this link is more mixed (review: Butler 2005). For example, during early lactation, infusion of insulin, associated with control of glycaemia, failed to stimulated LH pulse frequency, but did stimulate production of oestradiol by a direct action on the ovary (Butler et al. 2004). It appears that insulin does not always stimulate GnRH secretion, especially in presence of strong negative feedback.

\section{Growth Hormone (GH)}

The presence of mRNA for GH receptors in the hypothalamus and the pituitary gland (Kirby et al. 1996; Lucy et al. 1998) suggests that GH could link nutritional inputs to gonadotrophic outputs (Monget \& Martin 1997). Energy balance certainly affects plasma concentrations of $\mathrm{GH}$ under a wide variety of conditions (Bossis et al. 1999) but, in male sheep at least, it is not likely to be involved in the stimulation of $\mathrm{Gn} R \mathrm{H}$ secretion because an increase in nutrition induces a decrease in plasma GH concentrations (Miller et al. 1998).

\section{Insulin-like growth factor-I (IGF-I)}

In male sheep, circulating concentrations of IGF-I are affected by diet and peripheral administration of physiological doses of IGF-I inhibits LH secretion, but this is probably through an action at pituitary level rather than by a change in GnRH pulse frequency (Adam et al. 1998). In addition, concentrations of IGF-I in CSF are not affected by diet (Miller et al. 1998) and we have not be able to demonstrate that IGF-I infusion into the third ventricle affects $\mathrm{LH}$ pulse frequency (Blache et al. 2000). It therefore seems likely that, in male sheep at least, IGF-I is not heavily involved in the effects of changes in nutritional status on the brain's reproductive centres. In the post-partum cow, plasma concentrations of IGF-I are negatively correlated with extended PPAI and positively correlated with body condition and food intake (Beam \& Butler 1999). Plasma IGF-I vălues decrease in food-restricted heifers and, in post-partum dairy cows, IGF-I increases linearly up to the day of first ovulation (Beam \& Butler 1997; Diskin et al. 2003). Also, IGF-I and its receptor have been found in the hypothalamus of the rat (Bohannon et al. 1988; Schechter et al. 1994) so IGF-I might play a direct role in the control of GnRH neurons and could be involved in the resumption of cyclicity in lactating cows (Beam \& Butler 1997; Diskin et al. 2003). However, until this concept is tested directly in cattle, the information from studies with rams leads us to conclude that it is unlikely.

\section{Thyroid hormones}

Thyroid hormones play a role in the control of seasonal reproduction in sheep, probably through an input into endogenous cerebral rhythms (Karsch et al. 1995). However, in the mature male sheep, the concentrations of thyroid hormones in plasma and CSF are not affected by the acute elevations of nutrition that increase LH pulse frequency, suggesting that they play no role in the rapid stimulation of the GnRH neurons (Miller et al. 1998; Zhang et al. 2004; 2005). In lactating cows also, there is little or no change in thyroid hormones in relation to selection for 
milk production (Veerkamp et al. 2003). Overall, there is very little evidence for thyroid hormones being important signals linking energy balance and reproduction. Arguably, this is not surprising because the ubiquitous action of thyroid hormones is not compatible with a very specific action on the reproductive axis.

\section{Hormones secreted by adipocytes}

Our view of the role played by adipose tissue in the management of metabolic status has evolved from that of a passive energy reserve to that of a very active endocrine regulator of a multitude of bodily functions, including food intake, metabolism, immunity, thermoregulation and cardiovascular function, as well as reproduction (Ahima 2005; Cinti 2005; Kershaw \& Flier 2004). Of the 20 or more endocrine products of adipose tissue, leptin appears to be the most important regulator of reproductive activity in ruminants (review: Chilliard et al. 2005), although leptin is also the most studied of the adipocyte hormones and future research might reveal key roles for the others. The expression and release of leptin, and the sensitivity of gonadal and brain tissues to leptin, are all altered by short- and long-term changes in metabolic status. Moreover, numerous experiments in female and male sheep have shown that leptin can affect the neuroendocrine systems that control the activity of the reproductive axis (review: Adam et al. 2003; Chilliard et al. 2005). A recent study in dairy cattle has illustrated the close link between leptin concentrations and $\mathrm{LH}$ pulse frequency during the post-partum period (Kadokawa et al. 2006), although a triggering role for leptin in the termination of anoestrus it is not always supported (Chagas et al. 2006). Indeed, the consensus of the large amount of leptin literature is that the role of leptin is permissive rather than triggering, and this is logical because adipose tissue is only one of the three compartments of metabolic status.

Another interesting adipose hormone, adiponectin, has yet to receive the same interest as leptin but perhaps should do so because it is exclusively produced by adipose tissue and, in contrast to leptin, it stimulates energy expenditure without any effect on feed intake when it is infused into the cerebral ventricle of the rat (Ahima 2005). In male rat pituitary cells in culture, adiponectin reduces the expression of $\mathrm{GnRH}$ receptor and decreases the secretion of $\mathrm{LH}$ (Malagon et al. 2006). However, an effect of adiponectin on the activity of the $\mathrm{GnRH}$ neurons is yet to be demonstrated.

\section{Hormones secreted by the gastro-instestinal tract}

A most interesting potential candidate in the regulation of reproduction by metabolic status is ghrelin, a gut hormone that is the endogenous ligand of the $\mathrm{GH}$ secretagogue (GHS) receptor. In sheep, ghrelin secretion is inhibited by an increase in feed intake and stimulated by fasting (Sugino et al. 2004). In rodents, the distribution of GHS receptors overlaps that of GnRH in the arcuate nucleus (St-Pierre et al. 2003) and ghrelin decreases the secretion of LH (FernandezFernandez et al. 2004). Interestingly, ghrelin and GHS receptors are expressed in human and rat testis (Tena-Sempere 2005) and ghrelin is found in most reproductive tissues in both male and female sheep (Miller et al. 2005). In dairy cattle, Roche et al. (2006) measured plasma ghrelin concentration, pre- and post-feeding, during peak lactation (75 days postpartum) in animals of low and high genetic merit for milk production. High-merit cows produced more milk, consumed more pasture, and had higher plasma concentrations of ghrelin and $\mathrm{GH}$, than low-merit cows. Itoh et al. (2005) reported a decline in ghrelin concentrations as cows progressed from early to mid- to late lactation, suggesting greater ghrelin production in cows during negative energy balance. Clearly, this should be a high priority area for further study. 


\section{Direct inputs by nutrients}

Digestive processes lead to the production of critical nutrients, such as amino acids, fatty acids (volatile or non-volatile) and carbohydrates, that flow into the circulation and can act as signals in their own right. However, in ruminants there is no strong evidence that these molecules are major regulators of the secretion of GnRH pulses. In female sheep, pulsatile LH secretion is not affected by intravenous infusion of precursors of neurotransmitters of large-neutral amino acids (Downing et al. 1995; 1996; 1997). In contrast, studies with rams suggest that fatty acids, a major currency in energy transactions in ruminants, affect GnRH secretion (Blache etal, 2000). The role of glucose is less clear - in male sheep, intra-abomasal and intravenous infusions of glucose failed to stimulate LH secretion (Boukhliq \& Martin 1997; Boukhliq et al. 1996; Miller et al. 1995b). In dairy cattle, however, twice-daily drenching with propylene glycol, a propionate precursor and thus a source of glucose, can profoundly reduce PPAI in primiparous cows in low body condition (Chagas 2003). Indicators of energy status (body condition score, milk production, glucose, insulin, GH, IGF-1) were not altered by this treatment, but there was an increase in LH pulse frequency and in ovarian activity and, consequently, earlier ovulation postpartum. This suggests that there are nutritional inputs, perhaps some form of 'nutrient sensing or signalling', that are not associated with whole body energy status but can nevertheless stimulate the hypothalamic-pituitary-ovary axis in the early postpartum period (discussed further below). Through such a pathway, nutrients could trigger an endocrine response that would stimulate the reproductive axis. For example, it has been proposed the effects of propylene glycol on resumption of ovulation post-partum are due to the stimulation of an insulin spike (Miyoshi et al. 2001) that acts as a signal to increase LH secretion and therefore evoke ovulation.

\section{Interactions among the elements of the communicational network}

Several levels of integration are needed because metabolic status at any given time depends on the status of all three key compartments - intake, storage and expenditure. The necessary interactions are managed by several hormonal systems, perhaps best exemplified by leptin secretion because it is affected by intake and expenditure as well as storage (mass of adipose tissue). In turn, leptin can stimulate the activity of three other endocrine systems involved in controlling the reproductive axis; i) pancreatic insulin in fasted cattle, albeit only at a low dose (20 $\mu \mathrm{g} / \mathrm{kg}$ : (Zieba et al. 2003); ii) pituitary GH in female sheep (Henry et al. 2001) but apparently not normal-fed cattle (Zieba et al. 2005); and iii) thyroid hormones (Flier et al. 2000). In addition, leptin secretion is affected by other inputs, such as the products of digestion and absorption and autonomic neural activity. The autonomic effects are evident in the responses to challenges with beta-adrenergic analogues that decrease leptin sensitivity and stimulate lipolysis (Penicaud et al. 2000).

It is important to note that the ultimate level of integration is within the central nervous system (Fig. 2). The brain mechanisms involved in the sensing of metabolic status and in the connection of metabolic status to GnRH neuronal activity are poorly understood. Some sort of 'metabolic sensor' is thought to be localised in the arcuate nucleus and median eminence because receptors for leptin and insulin are found in these areas (Blache etal. 2002; Chilliard et al. 2005). The search for links between the GnRH cells and the neurons containing insulin and leptin receptors is continuing and there are many candidate intermediaries (see Blache et al. 2006). Orexins were initially among the most promising because of their sensitivity to energy balance (Taylor \& Samson 2003) but intracerebral injections of orexin A or B inhibit GnRH 
activity in mature Merino rams (Blache et al. 2003) so their relevance is questionable. On the other hand, we need to continue investigating the roles of the orexinergic pathways because high intakes of energy and protein dramatically reduce the expression of orexin receptor 2 in the paraventricular nucleus (Blache et al. 2006). We now need to test whether this change in sensitivity to orexins is linked to a change in reproductive activity or a change in food intake.

Recently, a new neuropeptide, kisspeptin, has been shown to stimulate GnRH and FSH secretion in male rodents (Gottsch et al. 2004; Irwig et al. 2004; Navarro et al. 2005) and to stimulate $\mathrm{GnRH}$ and $\mathrm{LH}$ secretion in female sheep (Messager et al. 2005). Importantly, the kisspeptin receptor is found in over $75 \%$ of GnRH neurons in male rats (Irwig et al. 2004) and kisspeptin can be seen as major player in the processing of inputs into the systems that regulate GnRH secretion (Dungan etal. 2006). Interestingly, the ligand acts through a membrane receptor so kisspeptin pathways could mediate the rapid responses of the GnRH system to acute changes in metabolic status. Research is needed to test whether kisspeptin secretion or expression is regulated by energy balance.

The interactions among peripheral signals (insulin, leptin, ghrelin, adiponectin) and the neuroendocrine systems (kisspeptin) need to be revealed if we are to understand the integratory role of the brain in the process that leads to the 'decision to reproduce'.

\section{4) The temporal dimension}

In this section, we consider the dynamic aspects of the responses to nutritional inputs, the effects of time per se, as seen in the effects of photoperiod and fetal programming, and, finally, the concepts of 'metabolic memory' and 'nutrient sensing', as we attempt to integrate the four dimensions into a unified theoretical framework.

\section{Dynamics of responses to change in nutrition}

In the ram, the response of the GnRH neurons to an abrupt change in nutrition is initially rapid and robust, but then fades over the next few weeks (Martin et al. 1994; Zhang et al. 2004). The rapidity of these responses is also consistent with the autonomic nervous system being involved at both brain and adipose levels. This could involve input from the digestive viscera to the brain via the vagus nerve, as is the case for satiety responses following a meal (Woods et al. 2004). Some nutrients that are absorbed very quickly, such as some volatile fatty acids, could also be involved in this rapid response. In fact, plasma concentrations of insulin increase about $3 \mathrm{~h}$ before the start of $\mathrm{GnRH}$ response to the initial increase in intake (Zhang et al, 2004).

In contrast, the long-term effect of nutrition on the ram testis, measured on a scale of several weeks, seems to be independent of changes in the primary, GnRH-based, control system (Hötzel et al. 1995). The mechanism involved has not been studied further but, again, leptin might be implicated because, in the rat at least, the testis contains leptin receptor and leptin can inhibit testicular steroidogenesis (Tena-Sempere et al. 1999; Tena-Sempere et al. 2001).

On an annual timescale, the role of nutritional inputs, as well as the types of response to those inputs, can vary substantially, especially in genotypes that experience seasonal changes in appetite (Rhind et al. 2002). Some suggestions have been forwarded for control systems that might implement these strategies: i) ghrelin expression in sheep testis responds to changes in photoperiod (Miller et al. 2005); ii) leptin secretion varies among seasons (Alila-Johansson et al. 2004); iii) brain expression of relevant neuropeptides is affected by photoperiod (Adam et al. 2000); iv) adipocytes receive sympathetic and parasympathetic innervations, at least in the Siberian hamster, a seasonal animal (review: Bartness et al. 2002) - the sympathetic input controls several functions (eg, lipolysis, regulation of adipocyte number) including, most inter- 
estingly, the secretion of leptin (Bartness et al. 2002); v) there are autonomic nervous projections from the adipocytes to the brain (Bartness et al. 2005), a connection that could provide metabolic information rapidly and directly to the reproductive centres (Fig. 2).

\section{Metabolic memory}

In both sheep and cattle, previous metabolic status influences the reproductive response of the animals to an increase in energy availability. With respect to adipose stores, mature rams in low body condition, but not rams in high body condition, show a robust and repeatable increase in LH pulse frequency in response to an increase in intake. In low body condition rams, the leptin response is also blunted but the response to insulin is not (Zhang et al. 2005). These observations suggest that i) neither insulin nor leptin are necessary for inducing an increase in GnRH pulse frequency in response to an increase in food intake, and ii) leptin secretion does not always respond to an influx of nutrients. In contrast, in mature, grazing dairy cows calving in good body condition, pre-calving dry matter intake has no effect on PPAI or on post-calving plasma concentrations of leptin, IGF-I, or GH (Roche et al. 2005). In contrast, in first lactation heifers that have a low body condition score ( 4 on a scale of 10) 6 weeks prepartum, there are clear responses to an ad-libitum intake in the pre-partum period, in both metabolic hormones and LH pulse frequency (Chagas et al. 2006). One group of heifers in this study calved with low body condition and also received ad libitum feed postpartum, but they did not respond to postpartum feeding and they had low LH pulse frequency and also a longer PPAI. Together, these three studies in cattle and sheep (Chagas et al. 2006; Roche et al. 2005; Zhang et al. 2005) are consistent with the notion of a 'metabolic memory' that modulates the stimulatory effect of nutrient intake according to the level of either energy reserves or energy expenditure (Fig. 3).
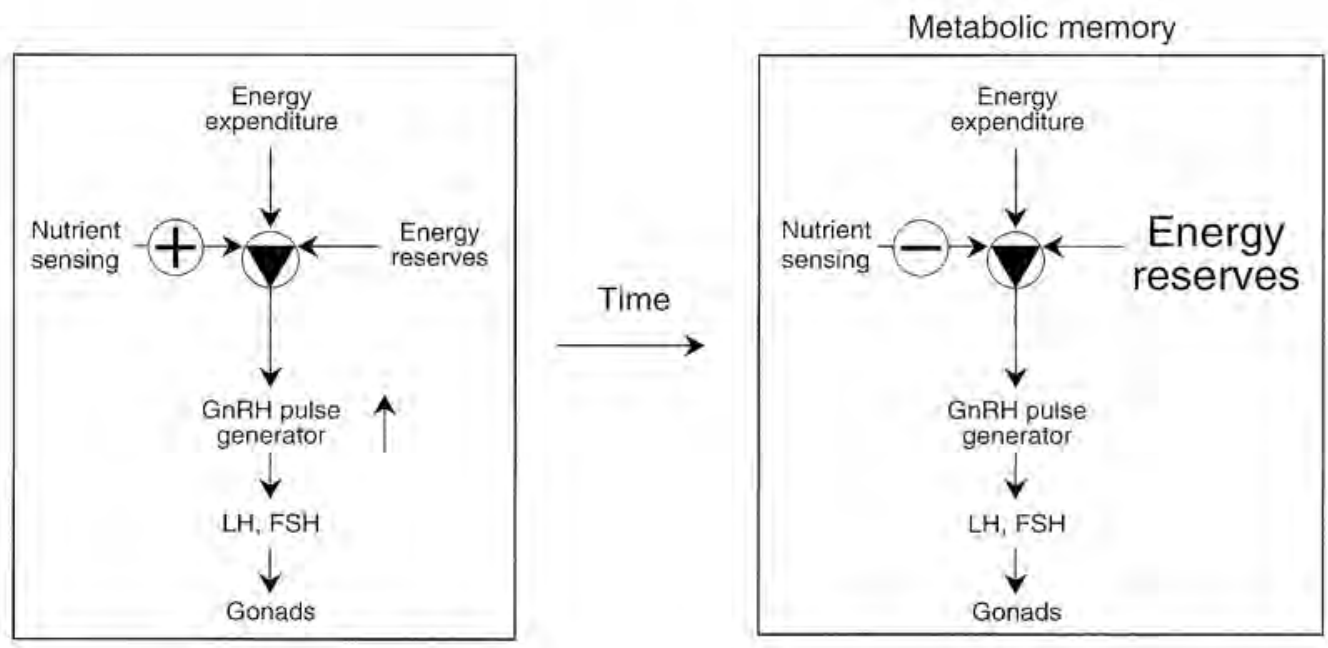

Fig. 3: A schema describing the potential influence of a 'metabolic memory' (here, an increase in body reserves) on the stimulatory effect of the nutrient influx (via 'nutrient sensing'), On the left panel, the energy reserves are low and the 'nutrient sensor' is able to stimulate the hypothetical 'metabolic sensor' in the brain and thus the GnRH pulse generator. With time, the level of energy reserves may increase, as shown in the right panel, and the input from the nutrient sensor is decreased. Note: nutrients might be still able to stimulate gonadal function by pathways that are $\mathrm{GnRH}$-independent. 
Recently, the processes that might underpin 'metabolic memory' have been investigated in sheep and cattle and the data suggest that leptin and insulin are central to the concept (Chilliard et al. 2005). For example, leptin stimulates LH secretion from pituitary explants of normal-fed but not fasted cows (Amstalden et al. 2003). With respect to energy expenditure, insulin increases leptin secretion in sheep maintained in their thermoneutral zone but not in sheep enduring cold stress (Asakuma et al. 2003). In addition, growth factors, such as insulin and growth hormones, also affect leptin secretion in whole animal studies and in isolated adipocytes (Chilliard et al. 2005), and could therefore also be part of 'metabolic memory'. Other endocrine factors secreted by adipose tissue or by the digestive system might also be involved: for example, several metabolic effects have been described for adiponectin in rodents, such as increased insulin resistance and fatty acid oxidation, and reduced glucose output by the liver (review: Diez \& Iglesias 2003). These interactions between endocrine systems and nutrient supply may effectively act as a sort of peripheral integratory mechanism that complements the brain's integratory mechanisms, with the combination being responsible for 'metabolic memory'.

\section{'Nutrient sensing'}

Short-chain fatty acids and glucose might also contribute to the 'metabolic memory' because they are known to regulate leptin secretion in cultured ruminant adipocytes (review: Chilliard et al. 2005). However, glucose is not always stimulatory in ruminants - for example, intravenous injection of glucose does not stimulate leptin secretion (Kauter et al. 2000) but infusion of glucose modifies the post-prandial pattern of leptin secretion in sheep carrying an extra copy of the $\mathrm{GH}$ gene (Kadokawa et al. 2003). However, in ruminants, volatile fatty acids (acetate, propionate, butyrate) are the main nutrients absorbed from the anterior digestive tract and they are converted to heavier fats for deposition via a well-known pathway of fatty acid synthesis. In rodents, fatty acids are directly involved in the regulation of leptin gene expression and leptin secretion (Shirai et al. 2004), and studies using cell culture have led to the development of a model to explain the mechanism by which glucose regulates leptin secretion from adipocytes (Mueller et al. 1998; Shirai et al. 2004). In this model, glucose, after being metabolised into pyruvate, acts on leptin gene expression and leptin secretion via the malonyl-coenzyme A fatty acid synthesis pathway, a crucial pathway in intracellular signalling in adipocytes (Shirai et al. 2004). Should a similar pathway exist in ruminants, it would allow volatile fatty acids produced by the digestive system, such as acetate (Annison et al. 2002), to regulate leptin secretion. Interestingly, a recent paper suggested that propionate does not stimulate leptin secretion in lactating cows (Bradford et al. 2006), in contrast to the results obtained in sheep (Lee \& Hossner 2002). This difference could be caused by differences in metabolic status, and differences in the responsiveness of adipocytes to short chain fatty acids. This issue needs to be resolved by further research.

Finally, nutrients might also be able to act directly on components of the reproductive axis - for example, both acetate and butyrate can modulate the responsiveness of the anterior pituitary gland to leptin, so pituitary tissue could also be a site of interaction between hormones and nutrients in the control of reproductive function. Conversely, pituitary hormones might affect the activity or responsiveness of adipose tissue because cultured adipocytes express receptors for several pituitary hormones, including $\mathrm{LH}, \mathrm{FSH}$ and GH (Schaffler et al. 2005). These receptors need to be investigated but they could be part of a descending pathway which regulates the activity of the adipocytes, not only according to metabolic status, but also according to the 'decision to reproduce' 


\section{Conclusions}

The 'decision to reproduce' is controlled by a range of factors and, amongst them, variation in metabolic status is one of the most important, especially for animals that have evolved in an environment where food supply is not predictable. Making a successful 'decision' depends on the integration of a large amount of information coming from a large number of organs. Over the last decade, the number and role of pathways involved in the link between metabolic status and reproductive activity has increased, and each pathway is acting in conjunction with the others. The latest developments suggest that the responses to each pathway vary with time so that, to fully understand the relationship between nutrition and reproduction, the temporal dimension (on scales of hours to years, or even a generation) should be considered because ruminants seem to be able to partition their energy, either from reserves or from nutrient intake, according to their metabolic history.

\section{Acknowledgements}

We would like to thank Ms Margaret Blackberry for her endless toil in the laboratory. These studies could not have been contemplated without the generous assistance of the students and staff of Animal Science (University of WA). Funding was supplied by the National Health \& Medical Research Council, the Australian Research Council, the CSIRO Division of Animal Production, the Australian Wool Corporation, the University of WA and the New Zealand Foundation for Research Science and Technology.

\section{References}

Adam CL, Findlay PA \& Moore AH 1998 Effects of insulin-like growth factor-1 on luteinizing hormone secretion in sheep. Animal Reprodiction Science $5045-56$.

Adam CL, Moar KM, Logie TJ, Ross AW, Barrett P, Morgan PJ \& Mercer JG 2000 Photoperiod regulates growth, puberty and hypothalamic neuropeplide and receptor gene expression in female siberian hamsters, Endocrinology 141 4349-4356.

Adam CL, Archer ZA \& Miller DW 2003 Leptin actions on the reproductive neuroendocrine axis in sheep. Reproduction Supplement 61 283-297.

Ahima RS 2005 Central actions of adipocyte hormones. Trends in Endocrinology and Metabolism 16307. 313.

Alila-johansson A, Eriksson L, Soveri T \& Laakso M-L 2004 Daily and annual variations of free fatty acid, glycerol and leptin plasmá concentrations in goats (Capra hircus) under different photoperiods. Comparative Biochemistry and Physiology - Part A: Molecular \& Integrative Physiology 138 119-131.

Amstalden M, Zieba DA, Edwards JF, Harns PG, Welsh TH, Stanko RL \& Williams GL 2003 Leptin acts at the bovine adenohypophysis to enhance basal and gonadotrophin-releasing hormone-mediated release of luteinizing hormones: differential effects are dependent upon nutritional history. Biology of Reproduction 69 1539-1544.

Annison EF, Lindsay DB \& Nolan IV 2002 Digestion and melabolism. In Sheep Nutrition, pp 95-118, Eds $M$ Freer \& $H$ Dove. Wallingford: CAB International.

Asakuma S, Morishita H, Sugino T, Kurose Y, Kobayashi S \& Terashima Y 2003 Circulating leptin response to feeding and exogenous infusion of insulin in sheep exposed to thermoneutral and cold environments. Comparative Biochemistry and Physiology - Part A: Molecular \& Integrative Physiology $134329-335$.

Bartness TJ, Demas GE \& Song CK 2002 Seasonal changes in adiposity: the roles of the photoperiod, melatonin and other hormones, and sympathetic nervous system. Experimental Biology \& Medicine 227 363-376.

Bartness IJ, Kay Song C, Shi H, Bowers RR \& Foster MI 2005 Brain-adipose lissue cross talk. The Proceedings of the Nutrition Society 64 53-64.

Beam SW \& Butler WR 1997 Energy balance and ovarian follicle development prior to the first ovulation postpartum in dairy cows receiving three levels of dietary fat. Biology of Reproduction 56 133-142.

Beam SW \& Butler WR 1999 Effects of energy balance on follicular development and first ovulation in postparlum dairy cows. Journal of Reproduction and Fertility Supplement $\mathbf{5 4} 411-424$.

Blache D, Chagas LM, Blackberry MA, Vercoe PE \& Martin GB 2000 Melabolic factors affecting the reproductive axis in male sheep. Journal of Reproduc tion and Fertility 120 1-11.

Blache D, Adam Cl \& Martin GB 2002 The mature 
male sheep: a model to study the effects of nutrition on the reproductive axis. Reproduction Supplement $59219-233$.

Blache D, Zhang S \& Martin GB 2003 Fertility in males: modulators of the acute effects of nutrition on the reproductive axis of male sheep. Reproduction Supplement $61387-402$.

Blache D, Zhang S \& Martin GB 2006 Dynamic and integrative aspects of the regulation of reproduction by metabolic status in male sheep. Reproduction, Nutrition, Development 46 379-390.

Bohannon NJ, Corp ES, Wilcox BJ, Figlewicz DP, Dorsa DM \& Baskin DG 1988 Localization of binding sites for insulin-like growth factor-1 IGF-I in the rat brain by quantitative autoradiography. Brain Research 444 205-213.

Bossis I, Wettemann RP, Welty SD, Vizcarra JA, Spicer L) \& Diskin MG 1999 Nutritionally induced anovulation in beef heifers: ovarian and endocrine function preceding cessation of ovulation. Journal of Animal Science 77 1536-1546.

Boukhliq R \& Martin GB 1997 Administration of fatty acids and gonadotrophin secretion in the mature ram. Animal Reproduction Science 49 143-159.

Boukhliq R, Miller DW \& Martin GB 1996 Relationships between the nutritional stimulation of gonadotrophin secretion and peripheral cerebrospinal fluid (CSF) concentrafions of glucose and insulin in rams. Animal Reproduction Science 41 201-204.

Bradford BJ, Oba M, Ehrhardt RA, Boisclair YR \& Allen MS 2006 Propionate is not an important regulator of plasma leptin concentration in dairy cattle. Domestic Animal Endocrinology 30 65-75.

Bruning J, Gautam D, Burks D, Gillette I, Schubert M, Orban P, Klein R, Krone W, Muller-Wieland D \& Kahn C 2000 Role of brain insulin receptor in control of body weight and reproduction. Science $2892122-2125$.

Butler WR 2000 Nutritional interactions with reproductive performance in dairy cattle. Animal Reproduction Science 60-61 449-457.

Butler WR 2005 Inhibition of ovulation in the postpartum cow and the lactaling sow. Livestock Production Science 98 5-12.

Butler ST, Pelton SH \& Butler WR 2004 Insulin increases. 17 B-estradiol production by the dominant follicle of the first postpartum follicle wave in dairy cows, Reproduction 127 537-545.

Cahill G 1980 Melabolic memory. New England Journal of Medicine 302 396-397.

Chagas LM 2003 Propionate precursor to reduce postpartum anoestrus in heifers. ANZ Dairy Vets Conference, Taupo, 215-220.

Chagas LM, Rhodes FM, Blache D, Gore PJS, MacDonald KA \& Verkerk GA 2006 Precalving feeding and body condition effects on metabolic responses and postpartum anestrus interval in grazing primiparous dairy cows, lournal of Dairy Science 89 1981-1989.

Chilliard Y, Delavaud C \& Bonnet M 2005 Leptin expression in ruminants: Nutritional and physiological regulations in relation with energy metabolism. Domestic Animal Endocrinology 29 3-22.

Cinti S 2005 The adipose organ. Prostaglandins, Leukotrienes and Essential Fatty Acios 73 9-15.

Diez II \& Iglesias P 2003 The rote of the novel adipocyte-derived hormone adiponectin in human disease. European Journal of Endocrinolgy 148293 300.

Diskin MG, Mackey DR, Roche JF \& Sreenan JM 2003 Effects of nutrition and metabolic status on circulating hormones and ovarian follicle development in cattle. Animal Reproduction Science 78 345-370.

Downing JA, Joss J \& Scaramuzzi RJ 1995 A mixture of the branched chain amino acids leucine, isoleucine and valine increases ovulation rate in ewes when infused during the late luteal phase of the oestrous cycle: an effect that may be mediated by insulin. Journal of Endocrinology 145 315-323.

Downing IA, Joss J \& Scaramuzzi RJ 1996 The effects of N-methyl-D, L-aspartic acid and aspartic acid on the plasma concentration of gonadotrophins, $\mathrm{GH}$ and prolactin in the ewe. Journal of Endocrinology 149 65-72.

Downing JA, Joss J \& Scaramuzzi R, 1997 Ovulation rate and the concentrations of $\mathrm{LH}, \mathrm{FSH}, \mathrm{GH}$, prolactin and insulin in ewes infused with tryplophan, tyrosine or tyrosine plus phenylalanine during the luteal phase of the oestrous cycle. Animal Reproduction Science 45 283-297.

Dungan HM, Clifton DK \& Steiner RA 2006 Minireview: Kisspeptin Neurons as Central Processors in the Regulation of Gonadotropin-Releasing Hormone Secretion. Endocrinology 147 1154-1158.

Fernandez-Fernandez R, Tena-Sempere M, Aguilar E \& Pinilla L 2004 Ghrelin effects on gonadotropin secretion in male and female rats. Neuroscience Letters 362 103-107.

Fierro LC \& Bryant FC 1990 Grazing activities and bioenergetics of sheep on native range in Southern Peru. Small Ruminant Research 3 135-146.

Flier JS, Harris M \& Hollenberg AN 2000 Leptin, nutrition, and the thyroid: the why, the wherefore, and the wiring [comment]. Journal of Clinical Investigation 105859861.

Frisch RE 1994 The right weight: body fat, menarche and fertility. Proceedings of the Nutrition Society 53 113-129.

Gong JG, Lee WJ, Garnsworthy PC \& Webb R 2002 Effect of dielary-induced increases in circulating insulin concentrations during the early postpartum period on reproductive function in dairy cows. Reproduction 123 419-427.

Gottsch ML, Cunningham MJ, Smith IT, Popa SM, Acohido BV, Crowley WF, Seminara S, Clifton DK \& Steiner RA 2004 A role for kisspeptins in the regulation of gonadotropin secretion in the mouse. Endocrinology 145 4073-4077.

Graham NM 1964 Energy exchanges of pregnant and lactating ewes. Australian fournal of Agricultural Research 15 127-14t.

Hampton JH, Salfen BE, Bader JF, Keisler DH \& 
Garverick HA 2003 Ovarian follicular responses to high doses of pulsatile luteinizing hormone in lactating dairy calle. Journal of Dairy Science $\mathbf{8 6} 1963$ 1969.

Henry BA, Goding IW, Tilbrook AJ, Dunshea F \& Clarke I) 2001 Intracerebroventricular infusion of leptin elevates the secretion of luteinising hormone without affecting food intake in long-term food-restricted sheep, but increases growth hormone irrespective of bodyweight. Journal of Endocrinology $16867-77$.

Horton TH \& Rowsemitt CN 1992 Natural selection and variation in reproductive physiology. In Marnmalian energetics : interdisciplinary views of metabolism and reproduction, pp 160-185, Eds TE Tomasi \& TH Horton. Ithaca, N.Y: Comstock Pub. Associates.

Hötzel MI, Walkden-Brown SW, Blackberry MA \& Martin GB 1995 The effect of nutrition on testicular growth in mature Merino rams involves mechanisms that are independent of changes in $\mathrm{GnRH}$ pulse frequency. Journal of Endocrinology 147 75-85.

Hötzel MJ, Walkden-Brown SW, Fisher JA \& Martin GB 2003 Determinants of the annual pattern of reproduction in mature male Merino and Suffolk sheep: response to a nutritional stimulas in the breeding and non-breeding season. Journal of Reproduction and Fertility 15 1-9.

Irwig MS, Fraley GS, Smith IT, Acohido BV, Popa SM, Cunningham MJ, Gottsch ML, Clifton DK \& Steiner RA 2004 Kisspeptin activation of gonadolropin releasing hormone neurons and regulation of KiSS-1 mRNA in the male rat. Neuroendocrinology $80264-$ 272.

Itoh F, Komatsu T, Yonai M, Sugino T, Kojima $M$, Kangawa K, Hasegawa $Y$, Terashima $Y$ \& Hodate $\mathrm{K} 2005 \mathrm{GH}$ secretory responses to ghrelin and $\mathrm{GHRH}$ in growing and lactating dairy cattle. Domestic Animal Endocrinology 28 34-45.

Kadokawa H, Briegel IR, Blackberry MA, Blache D, Martin GB \& Adams NR 2003 Relationships between plasma concentrations of leptin and other metabolic hormones in GH-transgenic sheep infused with glucose, Domestic Animal Endocrinology 24 219-229.

Kadokawa H, Blache D \& Martin GB 2006 Plasma leptin levels correlate positively with pulsatile LH secretion in early postpartum Holstein dairy cows. Journal of Dairy Science 89 3020-3027.

Karsch FJ, Dahl GE, Hachigian TM \& Thrun LA 1995 Involvement of thyroid hormones in seasonal reproduction. Journal of Reproduction and Fertility Supplement 49 409-422.

Kauter K, Ball M, Kearney P, Tellam R \& McFarlane JR 2000 The short term effect of adrenaline, insulin, and glucagon on plasma leptin levels in sheep: development and characterisation of an ovine leptin ELISA. Journal of Endocrinology 166 127-135.

Kershaw EE \& Flier IS 2004 Adipose tissue as an endocrine organ. Journal of Clinical Endocrinology and Metabolism 89 2548-2556.
Kirby CJ, Thatcher WW, Collier RI, Simmen FA \& Lucy MC 1996 Effects of growth hormone and pregnancy on expression of growth hormone receptor, insulinlike growth factor-I, and insulin-like growth factor binding protein-2 and -3 genes in bovine uterus, ovary, and oviduct. Biology of Reproduction 55996 1002.

Lamming GE \& Darwash AO 1998 The use of milk progesterone profiles to characterise components of subfertility in milked dairy cows. Animal Reproduction Science 52 175-190.

Lee SH \& Hossner KL 2002 Coordinate regulation of ovine adipose tissue gene expression by propianate. Joumal of Animal Science $\mathbf{8 0}$ 2840-2849.

Lucy MC, Boyd CK, Koenigsfeld AT \& Okamura CS 1998 Expression of somatolropin receptor messenger ribonucleic acid in bovine lissues. Journal of Dairy Science $\mathbf{8 1}$ 1889-1895.

Malagon MM, Rodriguez-Pacheco F, MartinezFuentes Al, Tovar S, Pinilla L, Tena-Sempere M, Dieguez C \& Castano IP 2006 Regulation of pituitary cell function by the adipokine adiponectin. Frontiers in Neuroendocrinology 27 35-35.

Martin GB \& Walkden-Brown SW 1995 Nutritional influences on reproduction in mature male sheep and goats. Journal of Reproduction and Fertility Supplement 49 437-449.

Martin GB, Fisher IS, Blackberry MA, Boukhliq R, Hötzel MJ, Shepherd K \& Walkden-Brown SW 1994 Nutritional and photoperiodic control of testicular size in Suffolk and Merino rams. Proceedings of the Australian Sociely of Animal Production 20427.

Martin GB, Tjondronegoro S, Boukhliq R, Blackberry MA, Briegel JR, Blache D, Fisher IA \& Adams NR 1999 Determinants of the annual pattern of reproduction in mature male Merino and Suffolk sheep: modification of endogenous rhythms by photoperiod. Reproduction, Fertility and Development 11 355-366.

Martin GB, Hötzel MJ, Blache D, Walkden-Brown SW, Blackberry MA, Boukliq R, Fisher IA \& Miller DW 2002 Determinants of the annual pattern of reproduction in mature male Merino and Suffolk sheep: modification of response to photoperiod by annual cycle of food supply. Reproduction, Fertility and Development 14 165-175.

Martin GB, Rodger J \& Blache D 2004 Nutritional and environmental effects on reproduction in small ruminants. Reproduction, Fertility and Development 16 491-501.

McNaughton LR, Verkerk GA, Parkinson KA, Macdonald KA \& Holmes CW 2003 Postpartum anoestrous intervál and reproductive performance of three genotypes of Holstein-Friesian cattle manage in a seasonal pasture-based dairy system. Proceedings of the New Zealand Society of Animal Production 60 77-81.

Messager S, Chatzidaki EE, Ma, D, Hendrick AG, Zahn D, Dixon J, Thresher R, Malinge I, Lomet D, Carlton MBL, Colledge WH et al. 2005 Kisspeptin directly stimulates gonadotropin-releasing hormone 
release via G protein-coupled receptor 54. Proceedings of the National Academy of Sciences (USA) 102 1761-1766.

Miller DW, Blache D \& Martin GB 1995a The role of intracerebral insulin in the effect of nutrition on gonadotrophin secretion in mature male sheep. Journal of Endocrinology 147 321-329.

Miller DW, Blache D \& Martin GB 1995 b Neuroendocrine mediation of the effects of nutrition on the reproductive system: another task for insulin? Western Australian Endocrine Sciences Symposium, Perth.

Miller DW, Blache D, Boukhliq R, Curlewis JD \& Martin GB 1998 Central metabolic messengers and the effects of diet on gonadotrophin secretion in sheep. lournal of Reproduction and Fertility $112347-356$.

Miller DW, Findlay PA, Morrison MA, Raver N \& Adam CL 2002 Seasonal and dose-depedent effects of intracerebroventricular leptin on $\mathrm{LH}$ secretion and appetite in sheep. Journal of Endocrinology 175 395404.

Miller DW, Harrison JL, Brown YA, Doyle U, Lindsay Adam CL \& Lea RG 2005 Immunohistochemical evidence for an endocrine/paracrine role for ghrelin inthe reproductive tissues of sheep. Reproductive Biology and Endocrinology 360 .

Miyoshi S, Pate IL \& Palmquist DL 2001 Effects of propylene glycol drenching on energy balance, plasma glucose, plasma insulin, ovarian function and conception in dairy cows. Animal Reproduction Science 68 29-43.

Monget P \& Martin GB 1997 Involvement of insulinlike growth factors in the interactions between nutrition and reproduction in female mammals. Human Reproduction 2 Supplement 1 33-52.

Mueller WM, Gregoire FM, Stanhope KL, Mobbs CV, Mizuno TM, Warden CH, Stern JS \& Havel PJ 1998 Evidence that glucose metabolism regulates leptin secretion from cultured rat adipocytes. Endocrinalogy $139551-558$.

Navarro VM, Castellano JM, Fernandez-Fernandez R, Tovar S, Roa J, Mayen A, Barreiro ML, Casanueva FF, Aguilar E, Dieguez C, Pinilla L, Tena-Sempere M 2005 Effects of KiSS-1 peptide, the natural ligand of GPR54, on follicle-stimulating hormone secretion in the rat. Endocrinology 146 1689-1697.

Obici S \& Rossetti L 2003 Minireview: nutrient sensing and the regulation of insulin action and energy balance. Endocrinology $1445172-5178$.

Patton J, Kenny DA, Mee JF, O'Mara FP, Wathes DC, Cook M \& Murphy JI 2006 Effect of milking frequency and diet on milk production, energy balance, and reproduction in dairy cows. Journal of Dairy Science 89 1478-1487.

Penicaud L, Cousin B, Leloup C, Lorsignol A \& Casteilla L. 2000 The autonomic nervous system, adipose tissue plasticity, and energy balance. Nutrition $16903-$ 908.

Rhind SM, Archer ZA \& Adam CL 2002 Seasonality of food intake in ruminants: recent developments in understanding. Nutrition Research Reviews 15 43-65.
Rhodes FM, Clark BA, Macmillan KL \& McDougall S 1998 Use of once daily milking compared with treatment with progesterone and oestradiol benzoate (ODB) in anoestrous cows. Proceedings of the New Zealand Society of Amimal Production 58 44-46.

Robinson II, Ashworth CJ, Rooke JA, Mitchell LM \& McEvoy TG 2006 Nutrition and fertility in ruminant livestock. Animal Feed Science and Technology 126 259-276.

Roche JR, Kolver ES \& Kay JK 2005 Influence of precalving feed allowance on preparturient metabolic and hormonal responses and milk production in grazing dairy cows. Journal of Dairy Science $\mathbf{8 8}$ $677-689$.

Roche JR, Sheahan AJ, Chagas I.M \& Berry DP 2006 Genetic selection for milk production increases plasma ghrelin in pasture-based dairy cows. Journal of Dairy Science 89 3471-3475.

Schaffler A, Binart N, Scholmerich I \& Buchler C 2005 Brain talks with fat - evidence for a hypothalamicpituitary-adipose axis? Neuropeptides 39 363-367.

Schechter R, Whitmire J, Wheet GS, Beju D, Jakson KW, Harlow R \& Gavin JR 1994 Immunohistochemical and in situ hybridization of an insulin-like sub. stance in fetal neuron cell cultures. Brain Research 636 9-27.

Shirai Y, Yaku S \& Suzuki M 2004 Metabolic regulation of leptin production in adipocytes: a role of fatty acid synthesis intermediates. Journal of Nutritional Biochemistry 15 651-656.

Sinclair KD, Revilla R, Roche JF, Quintans G, Sanz A, Mackey DR \& Diskin MG 2002 Ovulation of the first dominant follicle arising after day 21 postpartum in suckling beef cows. Animal Science 75 115-126.

St-Pierre DH, Wang L \& Tache Y 2003 Ghrelin: a novel player in the gut-brain regulation of growth hormone and energy balance. News in Physiological Sciences 18 - 242-246.

Sugino T, Hasegawa Y, Kurose Y, Kojima M, Kangawa K \& Terashima Y 2004 Effects of ghrelin on food intake and neuroendocrine function in sheep. Animal Reproduction Science 82-83 183-194.

Tanaka T, Nagatani S, Bucholtz DC, Ohkura S, Tsukamura H, Maeda K \& Foster DI 2000 Central action of insulin regulates pulsatile luteinizing hormone secretion in the diabetic sheep model. Biol. ogy of Reproduction 62 1256-1261.

Taylor MM \& Samson WK 2003 The other side of the orexins: endocrine and metabolic actions. American Journal of Physiology 284 E13-E17.

Tena-Sempere M 2005 Exploring the role of ghrelin as novel regulator of gonadal function. Growth Hormone \& IGF Research 15 83-88.

Tena-Sempere M, Pinilla L, González LC, Diéguez C, Casanueva FF \& Aguilar E 1999 Leptin inhibits testoterone secretion from adult rat testis in vitro. Journal of Endocrinology 161 211-218.

Tena-Sempere M, Pinilla L, Zhang FP, Gonzalez LC, Huhtaniemi I, Casanueva FF, Dieguez C \& Aguilar E 2001 Developmental and hormonal regulation of leptin receptor (Ob-R) messenger ribonucleic acid 
expression in rat testis. Biology of Reproduction $\mathbf{6 4}$ 634-643.

Veerkamp RF, Beerda B \& van der Lende T 2003 Ef fects of genetic selection for milk yield on energy balance, levels of hormones, and metabolites in lactating cattle, and possible links to reduced fertility. Livestock Production Science 83 257-275.

Woods SC, Benoit SC, Clegg DJ \& Seeley RJ 2004 Regulation of energy homeostasis by peripheral signals. Best Practice \& Research Clinical Endocrinology \& Metabolism 18 497-515.

Zhang S, Blache D, Blackberry MA \& Martin GB 2004 Dynamics of the responses in secretion of $\mathrm{LH}$, leptin and insulin following an acute increase in nutrition in mature male sheep. Reproduction, Fertility and Development 16 823-829.
Zhang S, Blache D, Blackberry MA \& Martin GB 2005 Body reserves affect the reproductive endocrine responses to an acute change in nutrition in mature male sheep. Animal Reproduction Science $\mathbf{8 8} 257$ 269.

Zieba DA, Amstaldem M, Maciel MN, Keisler DH, Raver N, Gertler A \& Williams GL 2003 Divergent effects of leptin on luteinizing hormone and insulin secretion are dose dependent. Experimental Biological Medicine 228 325-330.

Zieba DA, Amstalden M \& Williams GL 2005 Regulatory roles of leptin in reproduction and metabolism: A comparative review. Domestic Animal Endocrinology 29 166-185. 